\title{
Streptomyces inusitatus sp. nov.
}

\author{
TŌRU HASEGAWA, TOGO YAMANO, AND MASAHIKO YONEDA \\ Microbiological Research Laboratories, Central Research Division, Takeda Chemical Industries, Ltd., \\ Osaka 532, Japan
}

A new species of bacteria is described for which the name Streptomyces inusitatus is proposed. The organism is characterized by a blue mass of aerial mycelium, coiled spore chains, spores with smooth surfaces, and a nonchromogenic vegetative mycelium. The type strain of $S$. inusitatus is strain T-41575 (= IFO 13601).

During the course of a screening program for the detection of antibiotic producers among commonly occurring members of genera of the order Actinomycetales Buchanan, a streptomycete (strain T-41575) was isolated which produced a known antibiotic, oxamicetin (4) (= antibiotic T-41575 [2]), previously reported to be produced by a non-streptomycete (Arthrobacter oxamicetus [14]) and active against both gram-positive (including acid-fast) and gramnegative bacteria. Because this strain produces blue aerial hyphae, spiral spore chains, spores with smooth surfaces, and colorless vegetative mycelium, it is believed to be a member of a new species of Streptomyces. The name Streptomyces inusitatus is proposed for this new species, the type strain of which is T-41575.

\section{MATERIALS AND METHODS}

Bacterial strain. Strain T-41575 was isolated in April 1973 from a soil sample collected in Asuka Village, Nara Prefecture, Japan.

Morphological characterization. The morphologies of the spore chains and of the mycelia of the organism grown on glucose-asparagine agar (15), yeast extract-malt extract agar (International Streptomyces Project [ISP] no. 2) (9), and inorganic salt-starch agar (ISP no. 4) (9) at $28^{\circ} \mathrm{C}$ for 7 to 14 days were studied with a light microscope. Electron micrographs of the spores were obtained with a JEM-T7S electron microscope (Japan Electron Optics Lab. Co. Ltd.).

Cultural characterization. For the examination of its cultural characteristics, strain T-41575 was cultivated on the various ISP media suggested by Shirling and Gottlieb (12) and on several media recommended by Waksman (15). The strain was inoculated on glucose-asparagine agar at $28^{\circ} \mathrm{C}$ for 10 days. Spores were suspended in sterilized water, and a loopful of the suspension was used to inoculate each medium. Cultures were incubated at $28^{\circ} \mathrm{C}$ for up to 14 days and were observed at 7 and 14 days.

Physiological characterization. Media used for the physiological characterization of the strain were prepared by methods outlined by Waksman (15) and by Shirling and Gottlieb (9). Each culture was incubated at $28^{\circ} \mathrm{C}$ for 14 days except those in milk $\left(37^{\circ} \mathrm{C}\right.$, 21 days) and gelatin $\left(24^{\circ} \mathrm{C}, 21\right.$ days) media. Temper- ature requirements for growth were determined on yeast extract-malt extract agar (ISP no. 2) and glucose asparagine agar slants incubated for 14 days in a temperature gradient incubator (model TN-3) (Toyo Kagaku Sangyo Co. Ltd.).

Carbohydrate utilization. Carbohydrate utilization was investigated by the method described by Pridham and Gottlieb (7).

Cell wall analysis. A cell wall analysis of the strain was made by the method described by Becker et al. (1).

\section{RESULTS AND DISCUSSION}

Morphological characteristics. The vegetative mycelium of the strain did not fragment into coccoid or bacillary elements. The aerial mycelium was simply branched and terminated in open or closed coils of three or more volutions (Fig. 1). Sporangia, flagellated spores, and fragmented hyphae were not observed. Spores were ellipsoidal to cylindrical, 0.5 to 0.7 by 0.9 to 1.4 $\mu \mathrm{m}$, with smooth surfaces (Fig. 2).

Cultural characteristics. The cultural characteristics of the strain on various media are presented in Table 1. In general, no distinctive color of the vegetative mycelium was observed either on organic or on chemically defined media. The color of the aerial mycelium was bluegray on Czapek agar, glucose-asparagine agar, yeast extract-malt extract agar, inorganic saltsstarch agar, and tyrosine agar.

Physiological characteristics. A darkbrown, melanoid-like pigment was not produced on either tyrosine agar or peptone-yeast extractiron agar. Starch was hydrolyzed, gelatin was weakly liquefied, and milk was peptonized, but nitrate was not reduced. Growth of the strain was noted between 15 and $32^{\circ} \mathrm{C}$. Optimum growth occurred between 28 and $30^{\circ} \mathrm{C}$.

Carbohydrate utilization. Moderate growth was observed with maltose, lactose, glycerol, starch, and sodium citrate, and poor growth was observed with D-galactose and D-glucose. No growth was observed with $i$-inositol, D-mannitol, D-xylose, L-arabinose, L-sorbose, D-fruc- 


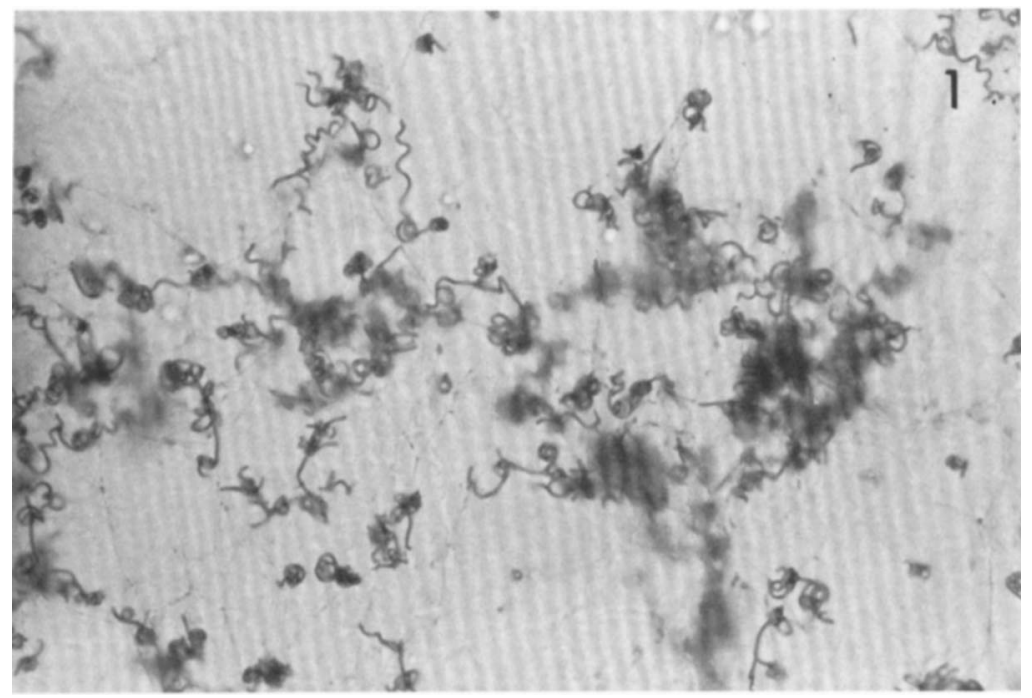

FIG. 1. Spore-bearing hyphae of strain T-41575 developing on the surface of glucose-asparagine agar. Optical microscope. Magnification, $\times 800$.

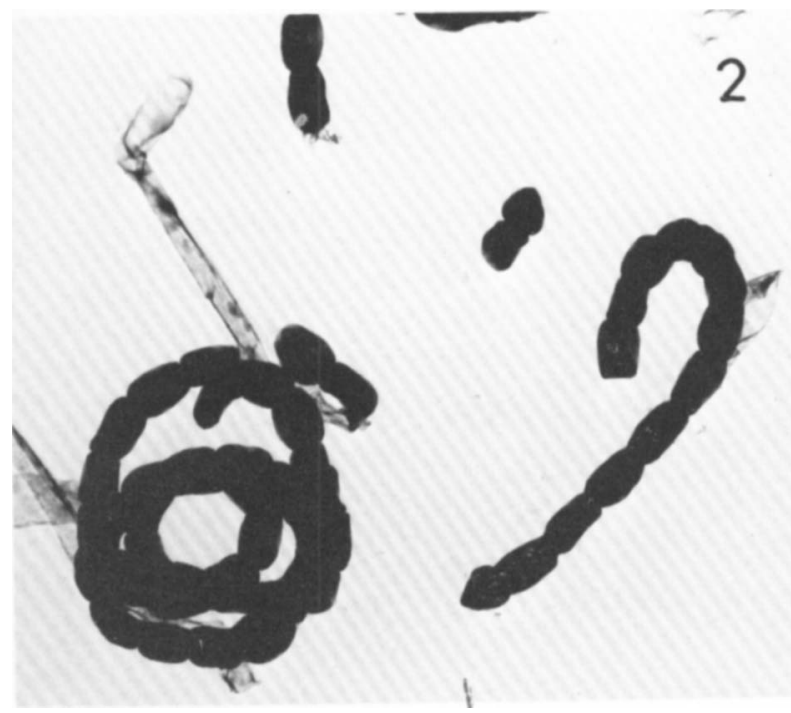

Fig. 2. Morphology and ornamentation of spores of strain T.41575. Electron microscope. Magnification, $\times 9,800$.

tose, rhamnose, sucrose, raffinose, trehalose, salicin, esculin, ribose, mannose, sodium acetate, or sodium succinate.

Cell wall analysis. Cell wall preparations of the strain contained L-diaminopimelic acid, glycine, aspartic acid, alanine, leucine, and glutamic acid as major constituents. Arabinose and galactose were not detected in hydrolysates. Based on these results, the cell wall of the strain was found to be of type I of Becker et al. (1), and the organism was assigned to the blue (B), spira (S), nonchromogenic $\left(\mathrm{C}^{-}\right.$), and glabrous (SM) groups as given by Pridham and Tresner in Bergey's Manual of Determinative Bacteriology, 8th ed. $(8)$, and to the blue (B), melanoid pigments (O), reverse-side pigments $(\mathrm{O})$, soluble pigments $(\mathrm{O})$, spirals (S), and smooth (sm) groups in Nonomura's key (6).

Comparison of strain T-41575 with known species. The taxonomic characters of strain T-41575 were compared with the descriptions of the known Streptomyces species which possess characters similar to those of strain $\mathrm{T}$ 41575. S. azureus $(8,10), S$. amakusaensis $(5,8$, 
TABLE 1. Cultural characteristics of Streptomyces inusitatus sp. nov. on various media

\begin{tabular}{|c|c|c|c|c|}
\hline \multirow[b]{2}{*}{ Medium } & \multicolumn{4}{|c|}{ Cultural characteristics" } \\
\hline & Growth & Aerial mycelium & $\begin{array}{l}\text { Color of reverse side } \\
\text { of colony }\end{array}$ & $\begin{array}{l}\text { Soluble pigment } \\
\text { production }\end{array}$ \\
\hline Czapek agar & $\begin{array}{l}\text { Moderate, re- } \\
\text { stricted, colorless }\end{array}$ & $\begin{array}{l}\text { Poor or moderate, pow- } \\
\text { dery, white to } 15 \mathrm{dc} \\
\text { (Dawn Blue) }\end{array}$ & Colorless & None \\
\hline $\begin{array}{l}\text { Glucose-asparagine } \\
\text { agar }\end{array}$ & Moderate, colorless & $\begin{array}{l}\text { Moderate, powdery, } \\
\text { white to Ife (Citron } \\
\text { Gray) to } 18 \mathrm{ec} \text { (Lt } \\
\text { Aqua) }\end{array}$ & $\begin{array}{l}\text { Colorless } \\
\text { ivory }\end{array}$ & None \\
\hline Nutrient agar & Moderate, colorless & Poor, white & Colorless & None \\
\hline $\begin{array}{l}\text { Calcium malate } \\
\text { agar }\end{array}$ & $\begin{array}{l}\text { Good, colorless to } \\
\text { ivory }\end{array}$ & None & Colorless & None \\
\hline $\begin{array}{l}\text { Yeast extract-malt } \\
\text { extract agar }\end{array}$ & $\begin{array}{l}\text { Good, wrinkled, } \\
\text { colorless to pale } \\
\text { yellowish brown }\end{array}$ & $\begin{array}{l}\text { Abundant, powdery to } \\
\text { velvety, white to 19dc } \\
\text { (Aqua Gray) }\end{array}$ & $\begin{array}{l}\text { Ivory to pale } \\
\text { brown }\end{array}$ & None \\
\hline Oatmeal agar & $\begin{array}{l}\text { Good, colorless to } \\
\text { pale yellowish } \\
\text { brown }\end{array}$ & Poor, white & $\begin{array}{l}\text { Pale yellowish } \\
\text { brown }\end{array}$ & None or ivory \\
\hline $\begin{array}{l}\text { Inorganic salt- } \\
\text { starch agar }\end{array}$ & $\begin{array}{l}\text { Good, wrinkled, } \\
\text { ivory }\end{array}$ & $\begin{array}{l}\text { Moderate, powdery, } \\
\text { white to } 19 \mathrm{dc} \text { (Aqua } \\
\text { Gray) }\end{array}$ & $3 g c(\mathrm{Lt}$ Tan) & None \\
\hline $\begin{array}{l}\text { Glycerol-asparagine } \\
\text { agar }\end{array}$ & $\begin{array}{l}\text { Moderate, re- } \\
\text { stricted, colorless }\end{array}$ & $\begin{array}{l}\text { Poor or moderate, pow- } \\
\text { dery, white }\end{array}$ & Colorless & None \\
\hline Tyrosine agar & Good, colorless & $\begin{array}{l}\text { Abundant, powdery, } \\
\text { 18gc (Dusty Aqua) }\end{array}$ & Colorless & None \\
\hline
\end{tabular}

${ }^{a}$ Color determinations were made by reference to the Color Harmony Manual (CHM), 4th edition (3), and noted by the CHM code number and CHM name.

$11)$, S. caelestis $(8,10)$, S. triangulata $(13)$, and $S$. ipomoea (12) were similar to strain T-41575 with respect to the color (blue) of the aerial mass and the spore surface (smooth). However, these taxa are readily distinguished from strain $\mathrm{T}$ 41575 by the following: $S$. azureus and $S$. caelestis produce melanoid pigments in tyrosine agar and peptone-yeast extract-iron agar; the aerial mass color of mature aerial mycelium of $S$. amakusaensis is of the green or blue color series on yeast extract-malt extract agar, this taxon produces melanoid pigments in peptoneyeast extract-iron agar, and mannose, arabinose, and raffinose are utilized for growth; there are three types of spores in the spore chains of $S$. triangulata (one type of spore is oval to cylindrical, as commonly formed by streptomycetes, one is triangular, and the other is " $T$ "'-shaped), and all three types have smooth surfaces; spore chains of $S$. ipomoea are usually short and give rise to hooks, loops, incomplete spirals, or spirals of only one or two turns; and L-arabinose, Dxylose, $i$-inositol, D-mannitol, D-fructose, rhamnose, sucrose, and raffinose are all utilized for growth by $S$. ipomoea.

To the best of our knowledge, there has not yet been reported a Streptomyces species of the blue series (color of aerial mycelium) which produces a nonchromogenic vegetative mycelium and coils of spores with smooth surfaces. On the basis of these observations, we believe that strain T-41575 represents a new species of Streptomyces, for which we propose the name $S$. inusitatus (in.usi.ta'tus; L. adj. inusitatus, unusual).

A detailed description of the new species follows.

Streptomyces inusitatus sp. nov.

Spore-chain morphology: Spore-bearing hyphae are simply branched and possess open or closed coils of spores. Sporangia, flagellated spores, and fragmented hyphae are not formed. The spores ( 0.5 to 0.7 by 0.9 to $1.4 \mu \mathrm{m}$ ) are ellipsoidal to cylindrical, have smooth surfaces, and are arranged in coiled chains.

Color of colonies: The color of the aerial mycelium is blue-gray to gray-blue on Czapek agar, glucose-asparagine agar, yeast extract-malt extract agar, inorganic salts-starch agar, and tyrosine agar.

Color of reverse side of colony: No distinctive pigments are formed on the reverse sides of colonies grown on either chemically defined or organic media.

Color in medium: No pigment or only a trace of ivory color is formed in oatmeal agar.

Physiological properties: Starch is hydrolyzed, gelatin is weakly liquefied, and milk is pepto- 
nized. Carbon sources such as maltose, lactose, glycerol, starch, and sodium citrate are utilized for growth. Poor growth is obtained with D-galactose and D-glucose.

Cell wall composition: L-Diaminopimelic acid, glycine, aspartic acid, alanine, leucine, and glutamic acid, but not arabinose and galactose, are contained in cell wall preparations. The cell wall is of type I of Becker et al.

Mesophilic.

Aerobic.

Antagonistic properties: Produces oxamicetin. Habitat: Soil.

Type strain: Strain T-41575. A culture of this strain has been deposited in the Institute for Fermentation, Osaka (IFO), under the accession number 13601 . Because the description given above for the species is based on a single strain, the type strain, the species description also serves as the description of the type strain.

\section{ACKNOWLEDGMENTS}

We thank H. A. Lechevalier, Waksman Institute of Microbiology, Rutgers University, New Brunswick, N.J., for critically reading the manuscript and for his valuable suggestions. We also thank E. Ohmura, R. Takeda, K. Nakazawa, and E. Higashide for their encouragement and discussion. The skillful technical assistance of S. Inuma is grateful acknowledged.

\section{REPRINT REQUESTS}

Address reprint requests to: Dr. Tōru Hasegawa, Microbiological Research Laboratories, Central Research Division, Takeda Chemical Industries, Ltd., 17-85, Juso-honmachi 2chome, Yodogawa-ku, Osaka 532, Japan.

\section{LITERATURE CITED}

1. Becker, B., M. P. Lechevalier, and H. Lechevalier. 1965. Chemical composition of cell-wall preparations from strains of various form-genera of aerobic actinomycetes. Appl. Microbiol. 13:236-243.

2. Hasegawa, T., S. Iinuma, M. Izawa, Y. Yamanaka, and H. Iwasaki. 1974. Production of oxamicetin by Streptomyces sp. T-41575. J. Takeda Res. Lab. 33:
179-185.

3. Jacobson, E., W. C. Grauville, and C. E. Fogs. 1958. Color harmony manual, 4 th ed. Container Corporation of America, Chicago.

4. Konishi, M., M. Kimeda, H. Tsukiura, H. Yamamoto, T. Hoshiya, T. Miyaki, K. Fujisawa, H. Koshiyama, and H. Kawaguchi. 1973. Oxamicetin, a new antibiotic of bacterial origin I. Production, isolation and properties. J. Antibiot. 26:752-756.

5. Nagatsu, J., K. Anzai, K. Ohkuma, and S. Suzuki. 1963. Studies on a new antibiotic, tuberin. IV. Taxonomic studies on the tuberin producing organism, Streptomyces amakusaensis. J. Antibiot. Ser. A 16:207-210.

6. Nonomura, H. 1974. Key for classification and identification of 458 species of the streptomycetes included in ISP. J. Ferment. Technol. 52:78-92.

7. Pridham, T. G., and G. Gottlieb. 1948. The utilization of carbon compounds by some Actinomycetales as an aid for species determination. J. Bacteriol. 56:107-114.

8. Pridham, T. G., and H. D. Tresner. 1974. Genus I. Streptomyces Waksman and Henrici, p. 747-846, In R. E. Buchanan and N. E. Gibbons (ed.), Bergey's manual of determinative bacteriology, 8 th ed. The Williams \& Wilkins Co., Baltimore.

9. Shirling, E. B., and D. Gottlieb. 1966. Method for classification of Streptomyces species. Int. J. Syst. Bacteriol. 16:313-340.

10. Shirling, E. B., and D. Gottlieb. 1968. Cooperative description of type cultures of Streptomyces. II. Species descriptions from first study. Int. J. Syst. Bacteriol. 18:69-189.

11. Shirling, E. B., and D. Gottlieb. 1968. Cooperative description of type cultures of Streptomyces. III. Additional species descriptions from first and second studies. Int. J. Syst. Bacteriol. 18:279-392.

12. Shirling, E. B., and D. Gottlieb. 1969. Cooperative description of type cultures of Streptomyces. IV. Species description from second, third and fourth studies. Int. J. Syst. Bacteriol. 19:391-512.

13. Shomura, T., Y. Yajima, S. Amano, and T. Niida. 1973. A new species of Streptomycetaceae: Streptomyces triangulata nov. sp. Sci. Rep. Meiji Seika Kaisha 72-79.

14. Tomita, K., Y. Uenoyama, K. Fujisawa, and H. Kawaguchi. 1973. Oxamicetin, a new antibiotic of bacterial origin. III. Taxonomy of the oxamicetin-producing organism. J. Antibiot. 26:765-770.

15. Waksman, S. A. 1961. The Actinomycetes, vol. 2. The Williams \& Wilkins Co., Baltimore. 